$\mathrm{ARCH}$

13,2

314

Received 22 February 2019 Revised 13 May 2019 Accepted 15 May 2019

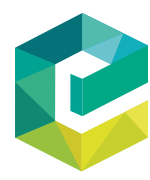

Archnet-IJAR: International Journal of Architectural Research Vol. 13 No. 2, 2019 pp. $314-330$ C) Emerald Publishing Limite 2631-6862 DOI 10.1108/ARCH-02-2019-0041

\section{Slums and prosperity: a complex, dynamic pathway of intervention}

\author{
Aisha Abubakar, Ombretta Romice and Ashraf M. Salama \\ Department of Architecture, Faculty of Engineering, \\ University of Strathclyde, Glasgow, UK
}

\begin{abstract}
Purpose - Slums have existed as long as cities have and are a growing context in the developing world. The challenge is in their efficient, effective and inclusive management. The purpose of this paper is to frame slums in the broad aim of urban development and the pursuit of prosperity, as active players and positive contributors in every right - a slum-prosperity framework. First, however, they need to be comprehensively defined in a non-exclusive, structured, dynamic and heuristic way; a previous publication was set to resolve this challenge.

Design/methodology/approach - Guided by a synthesized operative model for prosperity, such a definition for slums is used to precisely relate their characters to the pursuit of prosperity through a mapping process, whereby these characters are linked to potentials for prosperity, improvement goals, resources and intervention plans.

Findings - Both slums and prosperity are fuzzy, complex and variable terms; the only possibility to deal with them both is to break them down into simple and manageable yet operative units and establish the most influential and effective links between them to organize intervention according to patterns of change in both slums and city.

Research limitations/implications - An intervention agenda like the one proposed here, that gives room for contextual and temporal urban complexities, has the potential to augment urban practice and help curb the slum phenomenon. A final paper (forthcoming) will illustrate the application of both the comprehensive definition of slum and the implementation of a pathway toward prosperity.

Originality/value - The proposal in this paper is derived as part of research conducted for the award of a $\mathrm{PhD}$ at the University of Strathclyde Glasgow. This was in general set to contribute to the proactive and inclusive improvement of slums and cities. The proposal is further derived from the authors' involvement and personal interest in developing regions and is designed on local experience and on wider expertise in urban renewal.
\end{abstract}

Keywords Resilience, Intervention, Informal, Slums

Paper type Research paper

Introduction: slums in relation to urbanization, city growth and improvement in the quality of life

Slums have been a consistent part of urban development, in pre and post-industrial Europe and America in particular, long before it became a phenomenon predominantly associated with the developing regions. According to all past, current and forecast demographic data in these regions, slums are here to stay (UN-Habitat, 2003, 2016). Calls to find better and more effective ways of engaging them without aiding their further growth have persisted. Cities in developing regions are rightly concerned with maintaining productive enclaves, meeting global urban demands and maintaining sustainable and smart cities; slums are in general not regarded as advantages to their profiles (Alagbe, 2006; Satterthwaite, 2016). This perception has, since the 1950s, steered most approaches to slum management toward their elimination, benign neglect or containment. These approaches, in addition to prevailing pejorative perceptions, partial knowledge and non-integration of proactive strategies, have contributed to ineffective and sometimes even reverse outcomes that were the opposite of slum management aims (Arimah, 2010; UN-Habitat, 2014a, 2003).

However, in the past three decades especially, there has been some progress in dealing with slums in more positive ways involving on-site strategies to improve their overall living conditions. This, on the acknowledgment that destroying slums without 
resolving issues at their roots only fuels the growth of more slums. Some examples include the tenure model experimented in Voi, Kenya (Bassett, 2005), infrastructure and tenure strategies used in the Baan Mankong Program, Thailand (Boonyabancha, 2009) and the Participatory Slum Upgrading Program of the UN-Habitat. However, as the data between 2000 and 2014 show, these efforts remain dwarfed by the continued rise in absolute slum populations (Figure 1). The many layers of socially related, economic and environmental complexities intertwined in slums make understanding them and appropriately implementing interventions a challenge (Arimah, 2010; Jaitman and Brakarz, 2013). Slums are complex, yet properly understanding them seems key to their effective management. What is more, in history as of today, they share a complex existence with cities that are geographic and demographic as well as socio-cultural/economic/political in function. So, it is a two-way relationship between cities and slums.

\section{Slums are a relative concept}

We emphasize, as do Birch (2014), Halfani (2014) and Tannerfelt and Ljung (2006), that the challenge for developing region cities lies in the appropriate and inclusive management of slum urbanism if they are to progress sustainably. Not only that, but it is necessary to practically engage them with ongoing realities in cities' social, physical, economic, political

Trend in developing region urban slum populations and impact of slum upgrade: $1990-2014$

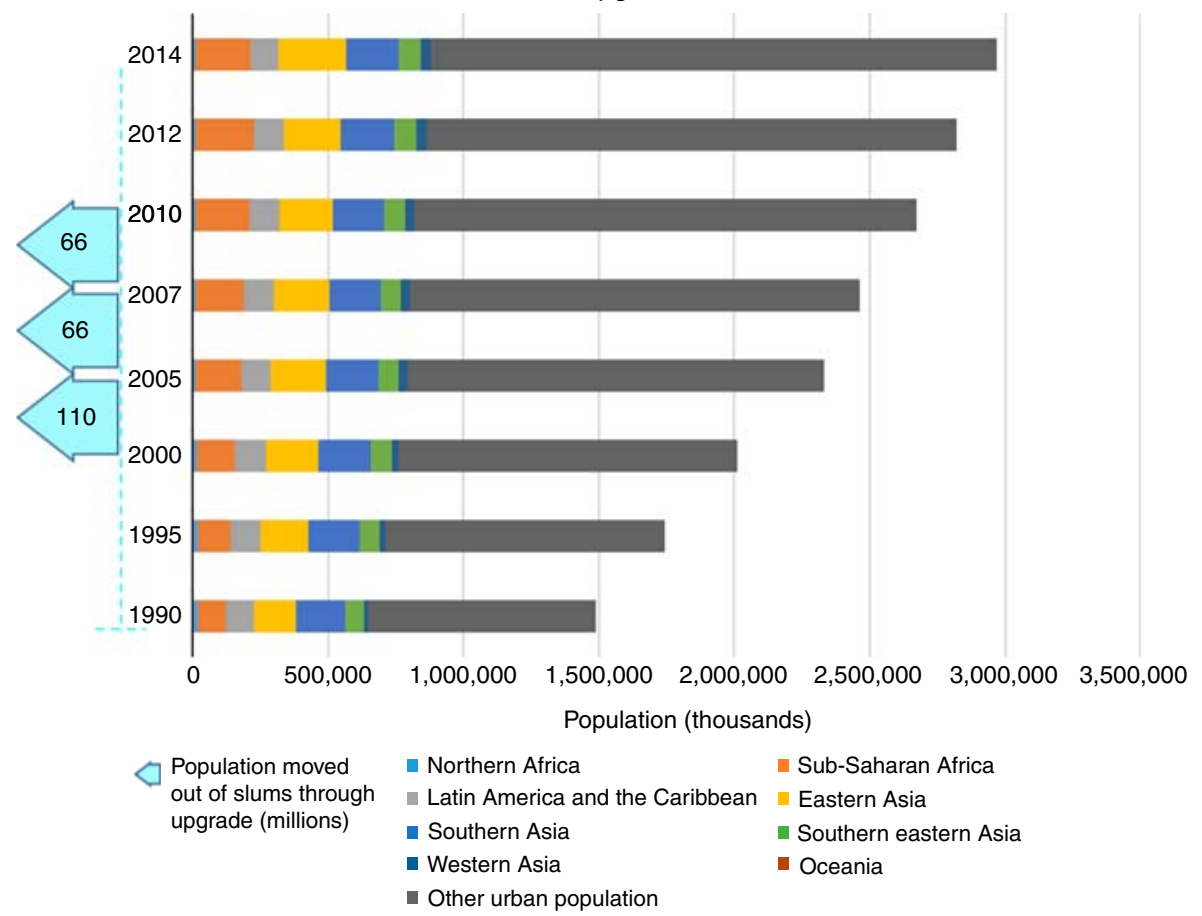

Note: In 2015, the UN-Habitat estimated a 28 percent rise in slum populations between 1990 and 2014 despite over $200 \mathrm{~m}$ slum population affected by slum upgrade

Source: (UN-Habitat, 2010, 2013a, 2016; United Nations, 2010)
Slums and prosperity 
$\mathrm{ARCH}$

13,2

316

and environmental spheres. To contribute to such an endeavor, we focus on associating slum urbanism and its improvement to a relevant urban concept and goal in cities' pursuit of progress and prosperity (see UN-Habitat, 2013a). For us, this involves overcoming two limitations: developing a systematic approach for the comprehensive description and definition of slums as they exist in the city. This is a prevailing gap for effective slum improvement and has been fulfilled through a proposal for the Slum Property Map (SPM) (Abubakar et al., 2017). The SPM is developed as a contextually sensitive framework to capture the physical, spatial and environmental image of slums, and dynamic to use in support of appropriate and strategic action. The second limitation to overcome consists in developing a definition of prosperity which is also comprehensive and operative and tied to slums and their characters. This approach can incite cities to engage their urban agendas with a "fresher notion of prosperity" (UN-Habitat, 2013a, p. XI) whilst effectively managing slums, so to improve their status within a global urban order.

The slum to its residents: looking from inside out: Cities serve as versatile and multidimensional engine rooms for human development (Halfani, 2014; UN-Habitat, 2013a). The most vibrant of cities in both historical and present-day contexts have always been "pulls" for populations seeking opportunities; the stories of cities' that are experiencing booms in social/ cultural/economic/political/ecological vitality parallel that of slums development, growth and persistence (Agnihotri, 1994; Angel, 2014; Glaeser, 2011; Payne, 2008). The primary objective for moving to or staying in cities is to improve wellbeing and have a better life overall. Because the pool of cities is for everyone, what varies is the starting condition one seeks to improve. For the poorest or disadvantaged, the slum in all its forms will always be a source of relatively accessible urban residence and, as current data shows, most times a permanent one. The UN-Habitat (2013a) established that in developing regions, 33 percent of an annual migration population of $1.3 \mathrm{~m}$ settles in slums. Since 2000, slums on average have grown by 16,500 persons a day or $6 \mathrm{~m}$ a year (UN-Habitat, 2016). So, the relations between cities' and slums' population growth extend beyond mere demographics and include all cities' vital structural dynamics.

The slum to the world: looking from outside in: Prosperity, for UN-Habitat (2013a), is a common ideal that cities' primary social, cultural, economic, political, ecological and urban management (and policy) structures are focused on attaining. However, while cities are paving ways toward prosperity, they are also generating issues of inequality, economic and environmental challenges (Halfani, 2014; UN-Habitat, 2013a). Cities in developing regions, in particular, pose a growing concern with regard to prosperity. Global consensus faults the presence of slums, along with aspects such as inadequate and inefficient planning policies, low average incomes, low levels of human capital, inadequate infrastructure, high levels of crime, poverty coupled with corruption, weak institutions and poor governance to be inconsistencies to cities' prosperity (UN-Habitat, 2013a, b; Weiss, 2001). All these dimensions are interrelated; for slums especially, poor governance, weak institutions and corruption are characteristic forces that continue to drive their growth. When prosperity is confined to a population group or not generally enjoyed by all, there is the need to re-assess cities within new dynamic perspectives (UN-Habitat, 2013a). Herein lies the potential to engage toward this idea: for the slums, cities hold certain potential for improvement and wellbeing overall; for the city, a way to pursue this objective is through prosperity. Slums are a part of cities and hold a substantial percentage of human capital. Then, why not consider prosperity as a goal that fits the slum as well in extending efforts toward sustainable urbanization? There is potential to streamline slum improvement with that of cities' prosperity.

\section{The idea of prosperity - a variable and non-standard concept}

A concept used historically, prosperity has only relatively recently been studied as a significant measure in a country's, city's or population's life. The most recent 
advancements in understanding prosperity have been three-fold: first, recognizing that from the perspective of wellbeing, prosperity is not solely linked to economic growth - an aspect highlighted by the long existing economic monopoly over a general conception of prosperity (see Cowling, 2006; Prescott, 2002). Rather, it also concerns social and environmental criteria that address growing rural/urban disparities. Second, acknowledging that prosperity is a relative concept rather than an absolute one; and third, that it is a dynamic endeavor.

For Jackson (2011), prosperity is a concept that is inextricably tied to human relations and to physical, social, and environmental continuity, responsibility and concern; it is also the flip side of poverty or adversity. For Ellin (2013), prosperity means to thrive in relation to coexisting personal, societal and environmental circumstances. Prosperity, for the UN-Habitat (2013a, pp. XI, 13), "means different things to different people; regardless of culture and civilization, it refers to a general individual and socioeconomic wellbeing and security for the immediate and foreseeable future. [...] [it] remains one of the human kind's most enduring pursuits across time and space." The Legatum Institute (2014) describes it as "more than just the accumulation of material wealth, [but] also the joy of everyday life and the prospect of an even better [...] future." For Shah (2012), people consider the relevance of the varying aspects of prosperity differently - some might consider the more social aspects more relevant to their wellbeing than economic.

A shared and accepted conceptualization of prosperity is still a work in progress; but again, since the early twentieth century, so are its relevant measurable targets (UN-Habitat, 2013a, 2015). This encompasses measures such as the gross domestic product (GDP) established in 1937, the 1972 gross national happiness measure in Bhutan, and the 2006 China's green GDP index. More recently, varying indicators of individual and collective wellbeing have been used to assess the levels of prosperity by organizations. Examples include the New Economics Foundation, UK that uses personal, psychological and social wellbeing indicators (Harrison et al., 2016) and Regional Research Institute, USA, that uses indicators of people, business and business location (UN-Habitat, 2013a). The UN-Habitat (2013a, 2015) sought to capture prosperity as a concomitant interplay of productivity, infrastructure, quality of life, equity, environmental sustainability and governance. For them, each of their proposed six dimensions is measurable and have helped compile the city prosperity index (CPI) with which to classify cities in both developed and developing countries. Six degrees of CPI were then put forward that provide an overview of required intervention to address shortfalls in each of the six dimensions (wheel of urban prosperity). For us, this approach provides a more inclusive way of looking at prosperity and has both a global outlook and local sensitivity.

An initial analysis of the UN-Habitat CPI measure for cities with weak prosperity revealed an interesting result: whilst the cities with lowest overall prosperity index are also those within regions of high slum percentages, the trend between slum development within the period of 1990-2009 and city prosperity does not show a recurrent inverse pattern (Figure 2). Inverse patterns happen consistently when slums develop within an ineffective policy and practice framework dealing with their management - considerably affecting aspects of equity and governance - in association with the characteristic forces that continue to drive their growth. A closer look at the case of Dhaka - where a more efficient approach to urban and slum management was implemented - shows that better prosperity is accompanied by a receding regional slum population trend. While Harare - where a less efficient urban/slum management approach was in place - showed instead that lower prosperity is accompanied by expanding regional slum population. This suggests that slums are not necessarily the prime cause of low prosperity in themselves and highlight the logic in considering prosperity pursuit in tandem with slum improvement in the overall greater pursuit of sustainable urbanization. 


\section{$\mathrm{ARCH}$}

13,2

\section{8}

Figure 2.

Analysis of city prosperity index for cities with weak prosperity factors, and the change in absolute slum populations for their country regions between 1990 and 2009
City prosperity and slum population comparison

900 0.700
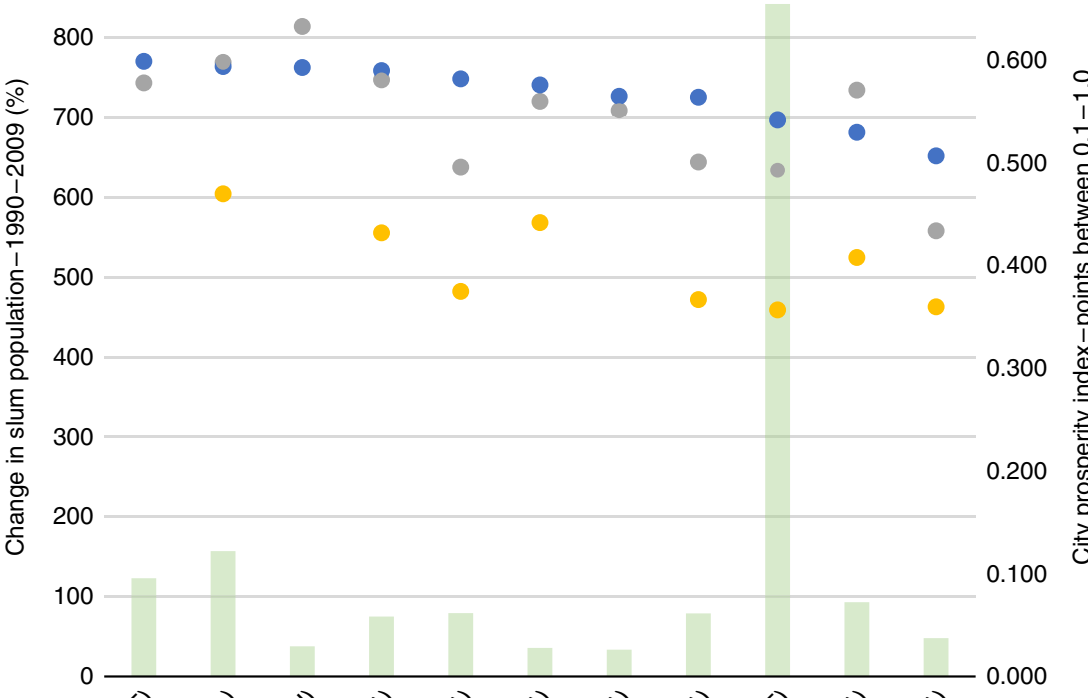

0.000

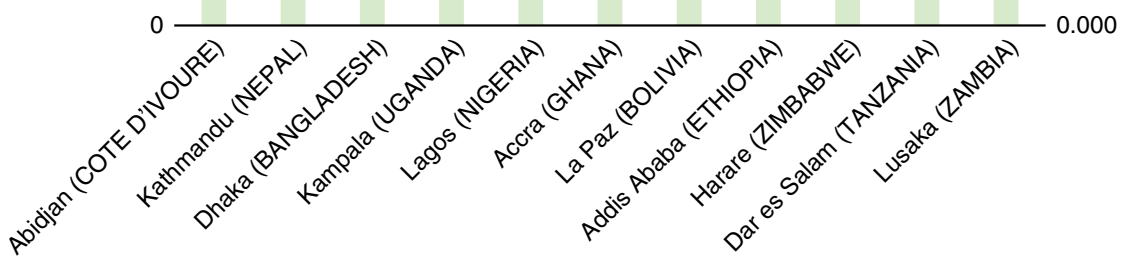

Weak prosperity cities (with country)

Change in absolute slum population by country region 1990-2009 (\%)

- CPI with 4 dimensions-productivity, infrastructure, quality of life, environmental sustainability

- CPI with equity

CPI with equity and governance (2015)

Source: UN-Habitat (2013a, 2015)

\section{Positively linking prosperity and slums: an approach}

The review of the literature shows the many and varied physical, social, spatial and environmental contexts that make up both cities and slums are complex, as are the outlooks on urban prosperity and the wellbeing concepts used to measure it. There is a lack of standardized conception of what it means to prosper. Furthermore, the measures of prosperity are broad, involve empirical analysis, and may not all necessarily apply to slums. They, however, reveal an interplay of three essential interactive real-life aspects: people and their interactions in the immediate space, the wider environment, and the structures in place to manage the people and environments. These aspects provide a useful frame for establishing an association between slum and prosperity because slums also contain people, environments and their interaction. At the same time, the UN-Habitat's wellbeing concepts provide a useful place to start to consider more contextually appropriate (to slums) and simpler to implement (for stakeholders concerned) indicators. For us, however, any effective slum-prosperity strategy will need to be based on a comprehensive understanding and 
definition of the slum and a detailed operative clarification of prosperity - what it means to prosper. The SPM (Abubakar et al., 2017) helps to define slums for intervention. The objective, therefore, was for a detailed clarification of prosperity and how this links to any slum's property map, and to enable stakeholders to slum improvement to efficiently take an active part in its pursuit. We approach such an agenda for slum and prosperity through integration of theory and framework development.

Romice et al. (2016) have suggested that quality of life in relation to cities is a dynamic process linked to people's personal and external conditions, and to the satisfaction of needs. On the assumption that overall prosperity is pursued through a combination of conditions, and is a consistent endeavor based on the fulfillment of goals then, we hypothesized that a comprehensive understanding of prosperity should be just as much about the pursuit of fulfillment, an inherent human quality that is tied to needs, as it is about the real-world dimensions of people, the wider environment, and the management structures in place. From this, we develop a theory and model that explains what it means to prosper and in slums, and the relevant stages involved. This theoretical construct is reached through the analytical synthesis of facts and concepts from theories of human motivation, needs and development, space and space production and resilience. It is proposed in the section "An operative overview of prosperity and its pursuit in slums." The next operational task, therefore, was to develop a comprehensive and actionable Slum-Prosperity Framework (SPF).

The SPF is a conceptual framework of actions to help stakeholders in slum improvement engage on a path to prosperity. We integrate the SPM (Abubakar et al., 2017) to describe the slum through a list of comprehensive categories of properties that characterize its form, people, activities, meanings and perceptions. We further integrate a framework of indicators to help appraise slums and their potentials for prosperity that are context specific and structured about people, environment and the management structures. On this basis, we combine the map of properties and prosperity to human needs requiring fulfillment in time, using an expanded and defined Max-Neef's (1992) framework of human needs, and the hurdles and possibilities toward this. We further implement Social Network Analysis (SNA) theory and tools. SNA helps to visually track, analyze and strategize about the relationships of complex social phenomena (Hansen et al., 2011; Newman, 2003). In the SPF, it is used as a tool to help establish and represent these complex links between characteristics, needs and potentialities, and to help visualize and identify the resulting pathways for improvement and prosperity. So far, the SPF has been tested through a desktop case study supported by the previous informal experience of an area in Abuja, Nigeria; and, finally tested in terms of the logic and applicability of its principles and structure, functions and expected outcomes in an expert opinion survey, validating it. The SPF is proposed in the section "The slum-prosperity framework."

\section{An operative overview of prosperity and its pursuit in slums}

Motivational behavior is a vital aspect of our inherent self-expression as humans just as our biological, organismic and personal, inherited, natural and social qualities; understanding the motives that guide pursuit of goals is tied to an understanding of needs, and how they award potency to goals (Deci and Ryan, 2000; Spirkin, 1983). MaxNeef's (1992) theory of human needs provides a functional view for the pursuit of needscentered goals. It distinguishes between basic needs that have to do with our nature and are necessary for survival (Hartley, 2010; Maslow, 1943): subsistence, protection, affection, understanding, participation, creativity, identity, leisure and transcendence; and existential needs, which have to do with our essential domains of "being," "doing," "having" and "interacting." For Max-Neef, the strive toward fulfilling basic needs to improve our conditions, our social relations and environment, is addressed through existential needs and their satisfiers. Satisfiers are the perceived tangible and intangible conditions (physiological, mental and psychological) we need to meet, the actions we need 
$\mathrm{ARCH}$

13,2

to undertake, the assets we need to have, and the interactions that need to happen. Importantly, satisfiers might at the same time help fulfill a need and trigger the satisfaction of others. So, depending on circumstances they can work as catalysts or latent assets, a trait that will be referred to later in the paper.

Essentially, the above process includes our contextualization (as satisfiers) and operationalization (as resources) of elements of our lived spaces to fulfill needs-centered goals. The lived spaces embody the physical, social, natural, our actions and thoughts (Lefebvre, 1991; see also Salama et al., 2016). Also, they can be identified and represented through an ontological and cognitive framework. Abubakar et al. (2017) proposed such a framework - the SPM, to capture these same elements and spaces of slums via descriptive property categories. As such, it is possible to establish a correspondence between the slum itself and the existential process of needs satisfaction.

The simple fulfillment of needs-centered goals that improve a condition entails selfactualization; and this fulfills development (Max-Neef, 1992). Development implies a beneficial change that occurs from one condition to another more advanced one (see Hamdi, 2004; Soubbotina, 2004) in the systematic pursuit of goals. So, as an operative concept, we propose that pursuing prosperity implies the first stage of development through the efficient use of both contextual and operative spaces. Here, a sustained state of development, ensuring it does not fall back to deprivation, presents a valid potential for prosperity.

The missing link between simple development and the pursuit of prosperity has to do with time. Time is the dimension within which our relation with, occupation and appropriation of spaces to pursue living occurs (Habraken, 1998; Lefebvre, 1991), instilling dynamism to these processes. Our position on sustaining development ties well with the idea of prosperity pursuit as a dynamic endeavor, and finds corroboration in the ideas of dynamic sustainability, thriving (Ellin, 2013) and resilience (Holling, 1973). Time entails a change in the domain of lived spaces, people and their relationships, where contextual changes in one domain also affect the other; if the existential system responds to these variations, if it learns from experience and improves its behavior and performance without losing its essence, then the system is resilient. Thriving in any setting, for us, implies sustained development pathways efficiently adapted to people's evolving needs in response to contextual variations of lived spaces and of people. It is the second and relevant stage for prosperity. This systematic conceptualization - of development and thriving - presents a model and basic agenda to engage slums in prosperity.

\section{The Slum-Prosperity Framework}

So far, we have shown that engaging with city and slums toward prosperity requires a structured and hands-on approach across the dimensions of people, their environments and management structures, and their complex and dynamic interrelations. Furthermore, that human needs, when satisfied, improve immediate states or conditions - development, and the progressive attainment of development in time, thriving, achieves prosperity; also, the process is contextually based on the quality of lived spaces and their functional capacity toward development, as per needs, and thriving. The SPF is proposed to engage a pool of stakeholders - locals, urban and design professionals, NGOs, government officials, etc., to carry out four actions in view of relevant and essential outcomes (Figure 3). The idea here is that to pursue prosperity in any slum, local stakeholders need to be able to take part in development and to participate in the territorial control and management of their spaces. It is only when slum communities are given rights to develop and thrive that they can participate in the production of the spaces that award vitality to cities, which is a collective right (see Sadri and Sadri, 2012; Ypi, 2014). The SPF integrates slum traits as established in the SPM (Abubakar et al., 2017) to prosperity indicators and basic human needs; then, it guides toward the identification of effective pathways for improving prosperity prospects in slums in a responsive way, supported by SNA theory and tools. 


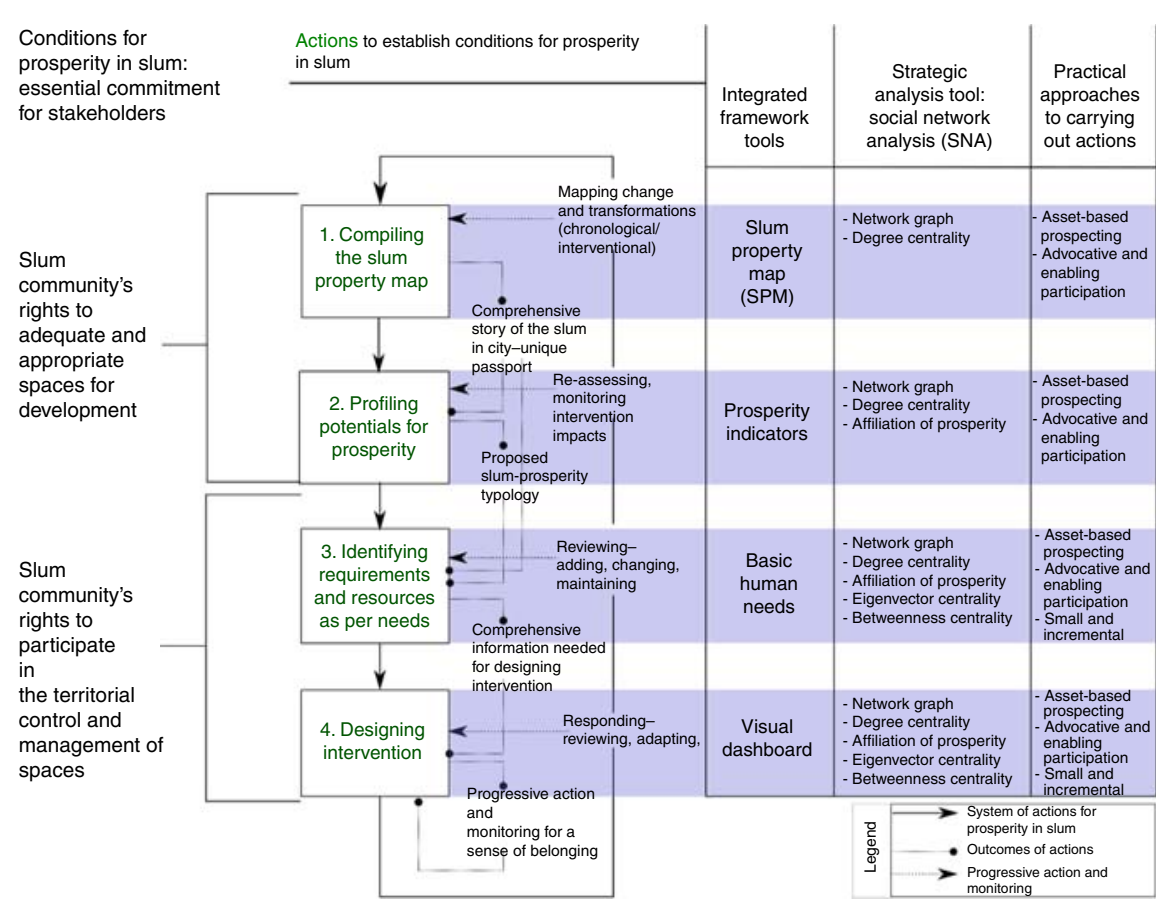

Source: Authors
Slums and prosperity

321

The first and second actions in the SPF - compiling the SPM, and profiling potentials for prosperity - are set to provide a comprehensive background about the slum and its prospects for prosperity, enough to guide a context-specific improvement approach. Here, applying an SPM manual (Abubakar et al., 2017) helps to compile the slum's property map through eight categories of slum properties with information and data that contextualize them; then, establish how and the degrees to which they affect/influence/trigger each other to define the slum's character. The narrative formed from it will capture the comprehensive image of the slum, its people, who they are, their attitudes, experiences, relevant activities, priorities, conditions and situations they live with and within, risks, interest in improving the slum, etc., a unique definition and story of its existence in the city. This exercise reveals a framework within which to consider how the slum character might enhance or inhibit the pursuit of development toward prosperity. For us, this pursuit is not a mechanical endeavor, rather, contextually based on the quality of slum's lived spaces, which can be assessed through its SPM. The instructions on how to undertake this action are based on simple logic with the support of the framework of 54 prosperity indicators that can be simply matched to the framework of slum properties (Figure 4). These are model contexts that will ideally support development, thematically grouped around dimensions of people, environments and management structures. They are proposed from a detailed qualitative content analysis based on the individual and collective urban wellbeing concepts of productivity, quality of life, infrastructure, equity, environmental sustainability and governance (see UN-Habitat, 2013a, 2015) using 33 published sources. Taking a positive outlook, the overall degree to which the slum space enhances prosperity, on a scale of overall slum-prosperity map, provides an index of the slum's propensity for and relative distance from prosperity. This can serve as a typology for the slum in the city, a point of reference and objective pace-setter. 


\section{$\mathrm{ARCH}$}

13,2

322

Figure 4.

A framework of indicators for prosperity, which can match any slum property map that defines a slum (see the Appendix for an enlarged version of the diagram)

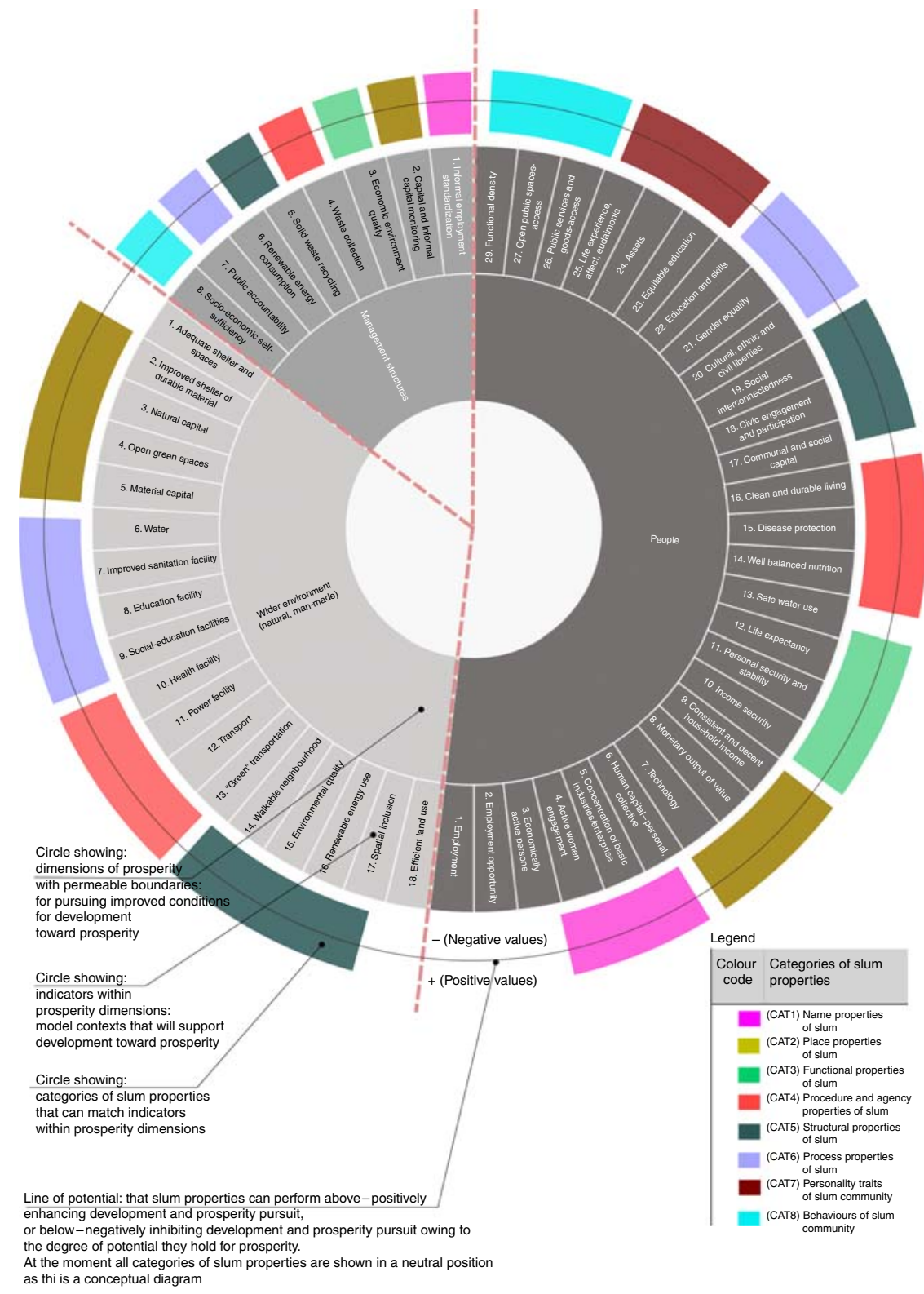

Notes: see Figures A1-A3 for an enlarged version of the diagram

Source: Authors

Once developed, the interactive slum-prosperity map will reveal relevant facts about the nature of the slum, through its properties, which stakeholders can qualify to highlight their role in possible development and thriving (action 3): by understanding the links between properties and their relationships, and thus establish their network-like character where 
some will have higher and others lower impact, by establishing how such properties might enhance or inhibit the pursuit of development toward prosperity, by establishing their capacity to widely impact positive change in the slum, acting as eigenvectors (see Hansen et al., 2011), and to act as triggers, brokers or partners toward positive change - essentially "starting-blocks" or "bridge-builders." These steps are strategically used to first identify key initial manageable, yet structured targets of engagement to upscale and/or correct with potential to support basic needs pursuit and incremental planning. This action is supported by the definition framework of basic human needs, developed through qualitative content analysis using 60 published sources. The SPF then helps to identify appropriate resources to capitalize on such initial change, and slowly, but systematically, pursue incremental improvement in association with slum community's assets. The above are the first steps to establishing relevant responsive pathways that can then be followed in a program to improve slum conditions and enable the communities to thrive and prosper (action 4). Any slum-prosperity program will need to target all milieus of development activities - people, their relations and environment, be flexible and allowed to adapt when needed and keep delivering small improvements along the way with proper tracking and monitoring. It will need to engage, guide and adequately enable the slum community, through human capacity building and rigorous guidance for one, toward primary implementation and its maintenance even after intervention has drawn to a close.

The objective of the SPF is to support and guide an informed and flexible decision-making process through triggering, engaging and empowering. Conceptually, the SPF is a map that links together a comprehensive and tailored description of the slum to a series of progressive actions, on the basis of resources with potential identified within, or Outwith the slum itself. It accounts for time and transformations along the way. It helps explore potential, capitalize on opportunities and intervene on obstacles. It is not an answer to slum prosperity, but a supported and calibrated journey toward its achievement. Hence, the actions and tools that we propose are not prescriptive, they allow for and encourage re-mappings, revisions and re-contextualization to appropriately respond to changes and evolutions in the slum. Because as things change, so also will improvement strategies. Thus, the SPF also serves as a knowledge base, learning, advocacy and partnership framework, especially with the implementation of a versatile, accessible and interactive visual dashboard (see Batty and Hudson-smith, 2014).

\section{Conclusions: a fresh perspective for slums' and cities' prosperity}

Continuing from Abubakar et al. (2017) that proposed a comprehensive slum definition framework - the Slum Property map (SPM), this paper has outlined an actionable framework - the Slum-Prosperity Framework (SPF), to assist in identifying and establishing effective pathways for slum improvement and urban prosperity overall. The SPM is, therefore, a key tool in the SPF. The SPF guides stakeholders to develop an intimate understanding of the state of affairs in a slum, establish synergies and requirements for improvement that are responsive to these and prosperity pursuit. Here, we consider that: an asset-based prospecting approach that recognizes the slum's social and mental, physical, environmental robustness without disregarding its challenges, an approach that advocates for and enables the slum community to play a vital and primary role in the process, and one that is not dismissive of small details and takes on small and incremental tasks are all key in view of creative and efficient processes and effective outcomes. Also, we implement the use of Social Network Analysis (SNA) theory and tools to support actions in the SPF. In the SPF, it helps stakeholders in the representation and documentation of facts, their analysis, assessments, evaluations and resolutions involved in the actions for prosperity. Just like the SPM, the SPF is also accompanied by an application manual, currently under development, which uses SNA software, NodeXL. For us, the SPF provides a novel approach to overcoming the perceptive and contextual challenges that are limitations to effective slum
Slums and prosperity 
$\mathrm{ARCH}$

13,2

intervention, and to advance sustainable, inclusive, and proactive slum and urban management. What is more, as a detailed map of properties, assets and needs, the SPF can also act as a useful tool to engage different stakeholders.

As noted previously, there is potential for a joint slum-prosperity endeavor in cities. However, our position is further supported by slums' vast partnership potential in terms of contributing social, spatial, natural, material, innovative and productive capital. Many provide accounts on the positive assets that slums hold, creative entrepreneurship, flexibility and perseverance (Neuwirth, 2005), a natural reliance on green and low impact energy solutions (Brand, 2010), inclusive and incremental development (Kellett and Napier, 1995), strong social, material, and human capital, and cultural identities (Abegaz, 2014; Alcantara, 2012; Turner, 1976) and local practical knowledge (Hamdi, 2010, 2004, 1995). There is, furthermore, general recognition of latent and active strengths that can work as assets toward the improvement of overall integrated living conditions making their communities effective, positive stakeholders in the process and with the wider city, rather than beneficiaries only (Hernandez and Kellett, 2010). Already, the informal city, in fact, plays supportive roles in cities (UN-Habitat, 2003, 2016), contributing a great percentage to their economy - Dharavi's estimated $\$ 500 \mathrm{~m}$ per day $/ \$ 30 \mathrm{bn}$ per year industry for one (Bhide, 2013; India, 2017), building innovation and housing workforce, etc. - Rocinha's mountainside of terrace houses for one (Leitão, 2008). So, it only makes sense that the informal city should be considered an asset in consolidating populations and strengthening cities' economies (Bertinelli and Black, 2004; Tannerfelt and Ljung, 2006). Some insist on the deeply intertwined set of relationships in cities to the point of proposing economic strategies that engage poverty populations in creating their own prosperity (Weiss, 2001).

And yet, there is little consideration for approaching slums with the programmatic intention of making them consistently and reliably instrumental in achieving prosperity overall. As such, the SPF fulfills a gap in the urban discourse, especially as it gives room for addressing both contextual and temporal complexities in slum management. Frameworks like these, as highlighted by the UN-Habitat in its highlights and a project report (UN-Habitat, 2014b) are important and still needed to augment ongoing urban initiatives. The application and testing of the SPF through a desktop case study (as will be shown in a forthcoming paper) and expert opinions survey support a proof of concept for it. The logic behind this approach is that a slum-prosperity urban improvement framework ought to be conceptually sound and practical in addition to being applicable and transferrable to deal with ongoing realities in the development of both slum and city. It does, however, remain theoretical and conceptual, though robust in its approach. More work still needs to be done to turn the SPF application manual, with integrated SPM, into a fully operative tool. The ambition is to make them versatile and applicable to different contexts and circumstances by offering a method to gain, analyze, organize and operationalize information that is inclusive, realistic and meaningful to both slum communities and those tasked with city improvement. Overall, to transform them into a simpler planning manual for efficient implementation, to get intervention going and keep it going.

\section{References}

Abegaz, K. (2014), "The role of iddir in development for city slum and frontier subcities of Addis Ababa: the case of ACORD intervention areas (Master of Arts (public administration))", Indira Gandhi National Open University, New Delhi, April.

Abubakar, A., Romice, O. and Salama, A.M. (2017), "Defining slums using multidimensional and relational properties: a dynamic framework for intervention”, ArchNet-IJAR: International Journal of Architectural Research, Vol. 11 No. 2, pp. 34-54. 
Agnihotri, P. (1994), Poverty Amidst Prosperity, M D Publications Pvt Ltd, New Delhi.

Alagbe and O.A. (2006), "Combating the challenges of rise in urban slums in cities in developing world: a case study of lagos state", The Built Environment: Innovation Policy and Sustainable Development, Ota, January 24-26.

Alcantara, E. (2012), "Building houses as a way of creating place attachment", in Thwaites, K., Romice, O. and Edgarton, E. (Eds), Abstracts: IAPS 2012 Conference Abstracts on Human Experience in the Natural and Built Environment: Implications for Research Policy and Practice, iapsGlasgow, pp. 294-294.

Angel, S. (2014), "UN-habitat: making room for a planet of cities", NYU Stern, Urbanization Project, available at: http://urbanizationproject.org/blog/un-habitat-making-room-for-a-planet-of-cities\#. VGuKVvmsViJ (accessed November 17, 2014).

Arimah, B.C. (2010), "The face of urban poverty: explaining the prevalence of slums in developing countries", working paper, World Institute for Development Economics Research, Helsinki, available at: www.econstor.eu/handle/10419/54181

Bassett, E.M. (2005), "Tinkering with tenure: the community land trust experiment in Voi, Kenya", Habitat International, Vol. 29 No. 3, pp. 375-398, available at: https:/doi.org/10.1016/j.habitatint.2003.12.001

Batty, M. and Hudson-Smith, A. (2014), "Visual analytics for urban design”, UCL working paper series, UCL Centre for Advanced Spatial Analysis, available at: www.researchgate.net/publication/2 67636936_Visual_Analytics_for_Urban_Design

Bertinelli, L. and Black, D. (2004), "Urbanization and growth", Journal of Urban Economics, Vol. 56 No. 1, pp. 80-96, available at: https://doi.org/10.1016/j.jue.2004.03.003

Bhide, A. (2013), “'Dharavi-ground up’: a dwellers-focused design tool for upgrading living space in Dharavi”, No. 184, Commission for Development Studies at the Austrian Academy of Sciences, Mumbai.

Birch, E. (2014), "Slums and cities: past present and future", Global Urban Lectures, available at: www. youtube.com/watch?v=pFD7hPJ37Iw (accessed April 29, 2016).

Boonyabancha, S. (2009), "Land for housing the poor - by the poor: experiences from the Baan Mankong nationwide slum upgrading programme in Thailand", Environment and Urbanization, Vol. 21 No. 2, pp. 309-329, available at: https://doi.org/10.1177/0956247809342180

Brand, S. (2010), How Slums Can Save the Planet (News Magazine), Prospect: The Leading Magazine of Ideas, available at: www.prospectmagazine.co.uk/features/how-slums-can-save-the-planet (accessed October 17, 2014).

Cowling, K. (2006), "Prosperity, depression and modern capitalism”, Kyklos, Vol. 59 No. 3, pp. 369-381, available at: https://doi.org/10.1111/j.1467-6435.2006.00337.x

Deci, E.L. and Ryan, R.M. (2000), "The " what " and " why " of goal pursuits : human needs and the self-determination of behavior", Psychological Inquiry: An International Journal for the Advancement of Psychological Theory, Vol. 11 No. 4, pp. 37-41, available at: https://doi.org/ 10.1207/S15327965PLI1104

Ellin, N. (2013), Good Urbanism: Six Steps to Creating Prosperous Places, Island Press, Washington, DC.

Glaeser, E. (2011), Triumph of the City, Penguin Books, New York, NY.

Habraken, N.J. (1998), The Structure of the Ordinary: Form and Control in the Built Environment, The MIT Press, Cambridge, MAand London.

Halfani, M. (2014), "Global urban lectures: the notion of prosperity", Global Urban Lectures, available at: www.youtube.com/watch? $v=C L p 16 u C \_M m E$ (accessed April 25, 2016).

Hamdi, N. (1995), Housing Without Houses, Earthscan, London.

Hamdi, N. (2004), Small Change: About the Art of Practice and the Limit of Planning in Cities, Earthscan, New York, NY.

Hamdi, N. (2010), The Placemakers Guide: To Building a Community, Earthscan, London. 
$\mathrm{ARCH}$ 13,2

Harrison, E., Quick, A. and Abdallah, S. (2016), Looking Through the Wellbeing Kaleidoscope Results from the European Social Survey, New Economics Foundation, London.

Hartley, D. (2010), Understanding Human Need, Policy Press and Social Policy Association, Bristol.

Hernandez, F. and Kellett, P. (2010), "Reimaging the informal in Latin America", in Hernandez, F., Kellett, P. and Allen, L.K. (Eds), Rethinking the Informal City, Berghahn Books, New York, NY; Oxford, pp. 1-19.

Holling, C.S. (1973), "Resilience and stability of ecological systems", Annual Review of Ecology and Systematics, Vol. 4, pp. 1-23.

India: Race to the Moon (2017), BBC Click, BBC News, August 19, available at: www.bbc.co.uk/ programmes/n3ct0bvb (accessed August 24, 2017)

Jackson, T. (2011), Prosperity Without Growth: Economics for a Finite Planet, Routledge, London and New York, NY.

Jaitman, L. and Brakarz, J. (2013), "Evaluation of slum upgrading programs. Literature review and methodological approaches", Technical note, Inter-American Development Bank, Institutions for Development Sector (IFD), November.

Kellett, P. and Napier, M. (1995), "Squatter architecture? A critical examination of vernacular theory and spontaneous settlement with reference to South America and South Africa", Traditional Dwellings and Settlements Review, Vol. 6 No. 2, pp. 7-24.

Lefebvre, H. (1991), The Production if Space, Blackwell Publishing, Malden, MA; Oxford, Melbourne and Berlin.

Legatum Institute (2014), "Legatum prosperity index", Legatum Prosperity Index, available at: www.prosperity.com/\#!/ (accessed October 29, 2015).

Leitão, G. (2008), "From wood huts to buildings of seven floors: an analysis of the process of housing production in the slum of Rocinha in Rio de Janeiro, Brazil, over a fifty-year period", in Kidokoro, T., Okata, J., Matsumura, S. and Shima, N. (Eds), Vulnerable Cities: Realities, Innovations and Strategies, Vol. 8, pp. 141-168, available at: https://doi.org/10.1007/ 978-4-431-78149-3_7

Maslow, A.H. (1943), “A theory of human motivation”, Psychological Review, Vol. 50 No. 13, pp. 370-396.

Max-Neef, M. (1992), "Development and human needs", in Ekins, P. and Mar-Neef, M. (Eds), Real-Life Economics: Understanding Wealth Creation, Routledge, London, pp. 197-214.

Neuwirth, R. (2005), Shadow Cities: A Billion Squatters, A New Urban World, Routledge, New York, NY.

Newman, M.E.J. (2003), "The structure and function of complex networks", Society for Industrial and Applied Mathematics, E-Print Cond-Mat/0303516, Vol. 45 No. 2, pp. 167-256.

Payne, G. (2008), "Are architects and planners part of the solution or the problem? The role of professionals in facilitating or constraining access by the urban poor to land and housing in developing countries”, in Vestbro, D.U. (Ed.), Are Architects and Planners Obstacles to Slum Upgrading ?, Barcelona, pp. 13-21, available at: www.arcpeace.org/en/publications/item/ 164-are-architects-and-planners-obstacles-to-slum-upgrading

Prescott, E.C. (2002), "Prosperity and depression”, American Economic Review, Vol. 92 No. 2, pp. 1-15, available at: https://doi.org/10.1257/000282802320188916

Romice, O., Thwaites, K., Porta, S., Greaves, M., Barbour, G. and Pasino, P. (2016), "Urban design and quality of life", in Fleury-Bahi, G., Pol, E. and Navarro, O. (Eds), The Handbook of Environmental Psychology and Quality of Life Research, Springer, Cham, pp. 241-273, available at: https:// doi.org/10.1007/978-3-319-31416-7_14 
Sadri, H. and Sadri, S.Z. (2012), "[Re] appropriation of the city_ spatial rights and the use of space", Architecture as a Tool for the Re-Appropriation of the Contemporary City, Conference, Polis University, Tirana, October 9-11.

Salama, A.M., Wiedmann, F., Thierstein, A. and Ghatam, W.A. (2016), "Knowledge economy as an initiator of sustainable urbanism in emerging metropolises: the case of Doha, Qatar", ArchNet-IJAR: International Journal of Architectural Research, Vol. 10 No. 1, pp. 274-324, available at: https://doi.org/10.26687/archnet-ijar.v10i1.927

Satterthwaite, D. (2016), "Finding a place in the city; low-income housing sub-markets revisited", Rethinking Precarious Neighbourhoods: Works, Paths and Interventions, Paris, June, pp. 1-15.

Shah, H. (2012), "Prosperity and social capital: is India missing out", India at London School of Economics, available at: http://blogs.lse.ac.uk/indiaatlse/2012/11/02/prosperity-and-socialcapital-is-india-missing-out/ (accessed October 7, 2014).

Soubbotina, T.P. (2004), Beyond Economic Growth: An Introduction to Sustainable Development (WBI Learing Resources Sereis), The International Bank for Reconstruction and Development/The World Bank, Washington DC, pp. 7-11, available at: www.worldbank.org/depweb/english/beyond/ beyondco/beg_01.pdf

Spirkin, A.G. (1983), "Dialectical materialism”, Progress, available at: www.marxists.org/reference/ archive/spirkin/works/dialectical-materialism/ch05.html\#ch05-s01 (accessed July 10, 2016).

Tannerfelt, G. and Ljung, P. (2006), More Urban Less Poor: An Introduction to Urban Development and Management, Earthscan, London.

Turner, J.F.C. (1976), Housing by People, Marion Boyars Publishers, London.

UN-Habitat (2003), "The challenge of slums: global report on human settlements", No. 1844070379 , UN-Habitat, United Nations Human Settlements Programme, London and Sterling, VA.

UN-Habitat (2010), State of the World's Cities 2010/2011: Bridging The Urban Divide, United Nations Human Settlements Programme, London and Sterling, VA.

UN-Habitat (2013a), State of the World'S Cities 2012/2013: Prosperity of Cities, No. 9780415838887, Earthscan, New York, NY.

UN-Habitat (2013b), "UN-Habitat global activities report 2013 our presence and partnerships", No. 9789211334067 , UN-Habitat, Nairobi.

UN-Habitat (2014a), A Practical Guide to Designing Planing and Executing Citywide Slum Upgrading Programmes, United Nations Human Settlements Programme, United Nations Human Settlements Programme, Nairobi, available at: www.ohchr.org/Documents/Issues/Housing/InformalSettlements/ UNHABITAT_A_PracticalGuidetoDesigningPlaningandExecutingCitywideSlum.pdf (accessed October 1, 2018).

UN-Habitat (2014b), Post-Project Intervention Assessment: Kibera Integrated Water Sanitation and Waste Management Project, United Nations Human Settlements Programme, Nairobi.

UN-Habitat (2015), “The city prosperity initiative: 2015 global city report”, United Nations Human Settlements Programme, available at: http://cpi.unhabitat.org/sites/default/files/resources/ CPI_2015\%20Global\%20City\%20Report._0.pdf

UN-Habitat (2016), "Slum almanac 2015-2016", United Nations Human Settlements Programme, London and Sterling, VA.

United Nations (2010), “Over 200 million escape slums but overall number still rising”, UN report finds, UN News, available at: https://news.un.org/en/story/2010/03/332882-over-200-million-escapeslums-overall-number-still-rising-un-report-finds (accessed January 11, 2014).

Weiss, M.A. (2001), "Productive cities and metropolitan economic strategy", United Nation's International Forum on Urban Poverty, Fourth International Conference, Marrakech, October 16-19.

Ypi, L. (2014), “A permissive theory of territorial rights”, European Journal of Philosophy, Vol. 22 No. 2 , pp. 288-312, available at: https://doi.org/10.1111/j.1468-0378.2011.00506.x 


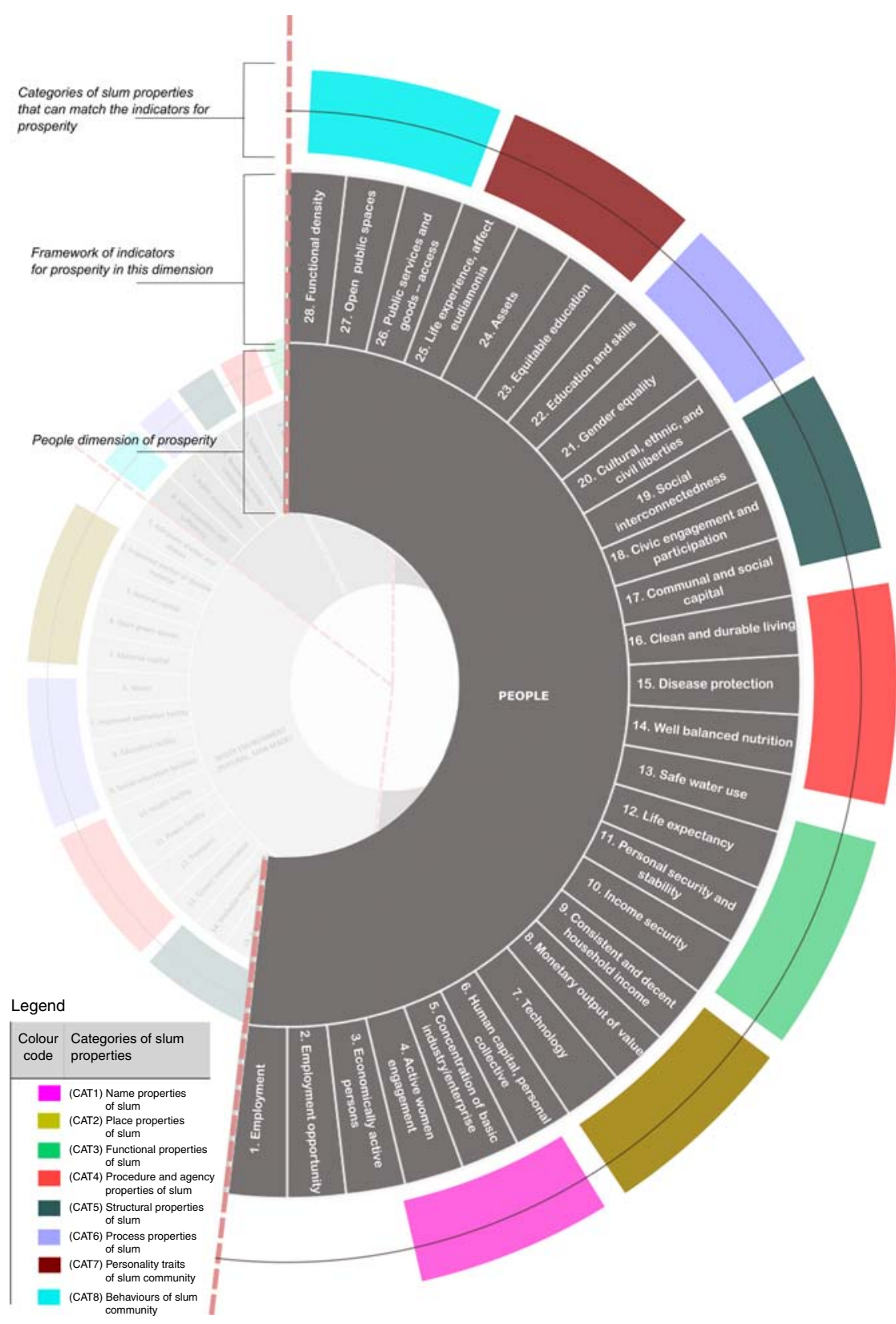

Figure A1.

A framework of indicators for prosperity relating to "people," which can match any slum property map that defines a slum

Source: Authors 


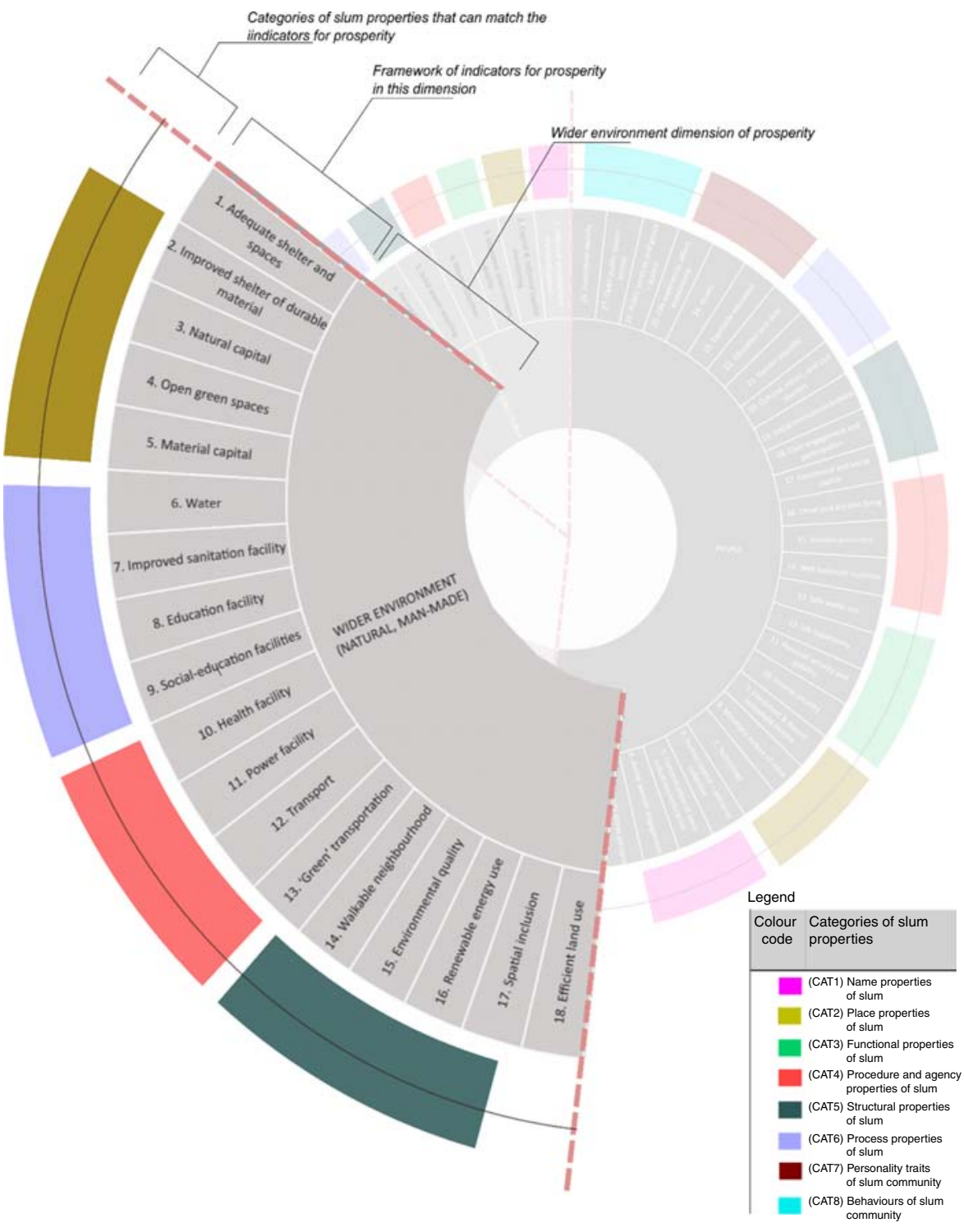

Slums and prosperity

Source: Authors

Figure A2.

A framework of Indicators for prosperity relating to "wider environment," which can match any slum property map that defines a slum 


\section{$\mathrm{ARCH}$ \\ 13,2}

330

Figure A3.

A framework of Indicators for prosperity relating to "management structures," which can match any slum property map that defines a slum

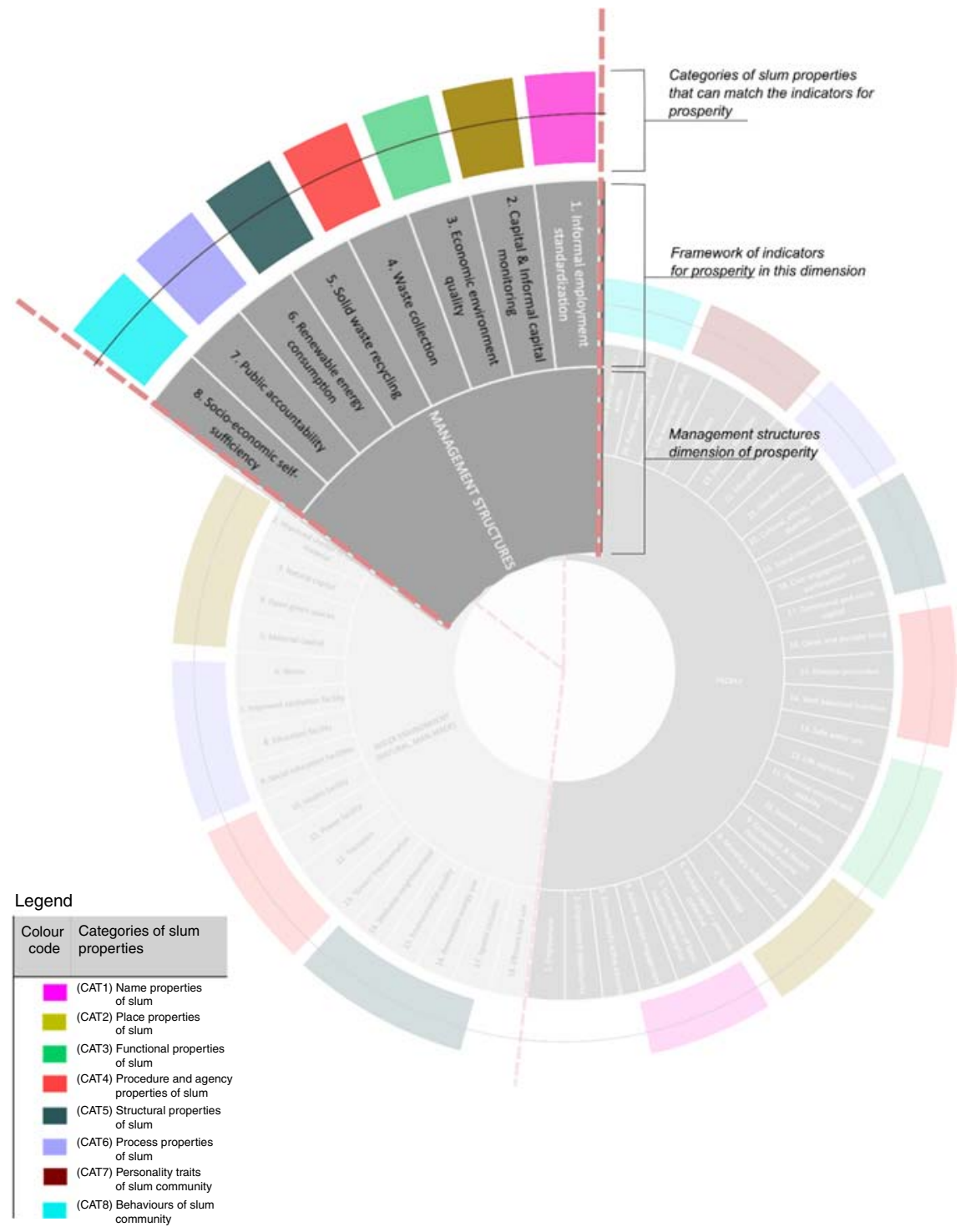

Source: Authors

\section{Corresponding author}

Aisha Abubakar can be contacted at: aisha.abubakar@strath.ac.uk

For instructions on how to order reprints of this article, please visit our website: www.emeraldgrouppublishing.com/licensing/reprints.htm Or contact us for further details: permissions@emeraldinsight.com 